\title{
Constrictibacter antarcticus gen. nov., sp. nov., a cryptoendolithic micro-organism from Antarctic white rock
}

\author{
Kozo Yamada, ${ }^{1}$ Wakao Fukuda, ${ }^{1}$ Yuka Kondo, ${ }^{2}$ Yuki Miyoshi, ${ }^{2}$ \\ Haruyuki Atomi ${ }^{2}$ and Tadayuki Imanaka ${ }^{1}$ \\ ${ }^{1}$ Department of Biotechnology, College of Life Sciences, Ritsumeikan University, 1-1-1 Nojihigashi, \\ Kusatsu, Shiga 525-8577, Japan \\ ${ }^{2}$ Department of Synthetic Chemistry and Biological Chemistry, Graduate School of Engineering, \\ Kyoto University, Katsura, Nishikyo-ku, Kyoto 615-8510, Japan
}

Correspondence

Tadayuki Imanaka imanaka@sk.ritsumei.ac.jp

\begin{abstract}
A Gram-negative, non-spore-forming, ovoid to rod-shaped aerobic or microaerobic bacterium, strain $262-8^{\top}$, was isolated from a cavity within white rock collected in Antarctica. Strain 262-8 grew at $5-30{ }^{\circ} \mathrm{C}$ (optimum $25^{\circ} \mathrm{C}$ ), at $\mathrm{pH} 6-8$ (optimum approximately $\mathrm{pH} 7$ ) and with $0.1-2.0 \%(\mathrm{w} / \mathrm{v}) \mathrm{NaCl}$ (optimum $0.5 \% \mathrm{NaCl}$ ). The addition of tryptone or yeast extract was essential for growth. Strain $262-8^{\top}$ was able to utilize organic compounds such as ribose, pyruvate and succinate in the presence of a low concentration of tryptone. Ubiquinone 10 was the major respiratory quinone. The major fatty acids were $\mathrm{C}_{18: 1}, \mathrm{C}_{16: 0}$ and $\mathrm{C}_{18: 0}$. The $\mathrm{G}+\mathrm{C}$ content of the genomic DNA was 69.8 mol\%. Comparative analyses of $16 \mathrm{~S}$ rRNA gene sequences and physiological characteristics indicated that strain $262-8^{\top}$ was a phylogenetically novel bacterium that should be classified in a new genus of the family Rhodospirillaceae, for which the name Constrictibacter antarcticus gen. nov., sp. nov. is proposed. The type strain of the type species is

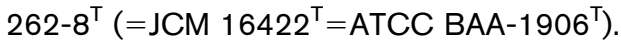

The climate in Antarctica, with its extreme cold and low concentration of organic materials, makes life difficult for most organisms. Moreover, the land surface is seasonally exposed to strong UV radiation (Bargagli, 2005; Hughes \& Lawley, 2003). Therefore, the diversity of plants and animals in Antarctica is limited. However, a great diversity of microorganisms has been found in Antarctica's icy environments, such as permafrost, polar oceans, snow, sea ice and a cryoconite hole (Prisco, 2007; Tindall, 2004). For example, micro-organisms, including cyanobacteria, have been found in perennial Antarctic lake ice in the McMurdo Dry Valleys (Priscu et al., 1998) and methanogenic archaea have been found in a frozen lake, Lake Fryxell (Karr et al., 2006). In addition, cryptoendolithic communities have also been found in the pore space of rock (de la Torre et al., 2003). Inhabiting the interior of rock is considered to be one alternative for survival in the harsh climate. Continuous summertime sunlight can raise the internal temperature of rocks above freezing point, up to $10{ }^{\circ} \mathrm{C}$ above the ambient temperature.

A white rock sample from the Skallen region in Antarctica was collected by the summer party of the 46th Japanese

The GenBank/EMBL/DDBJ accession number for the 16S rRNA gene sequence of strain $262-8^{\top}$ is AB510913.

Two supplementary figures are available with the online version of this paper.
Antarctic Research Expedition in 2004-2005. Interestingly, the interior of the white rock was colourful (green, pink, yellow and brown; Supplementary Fig. S1, available in IJSEM Online), which suggested the existence of a cryptoendolithic community containing cyanobacteria. Indeed, more than ten different bacterial species, including strain $262-8^{\mathrm{T}}$, were obtained from the rock sample. In this study, the identification of strain $262-8^{\mathrm{T}}$ was performed. Analysis based on 16S rRNA gene sequences indicated that strain $262-8^{\mathrm{T}}$ belonged to the order Rhodospirillales. The order Rhodospirillales in the class Alphaproteobacteria contains two families, Rhodospirillaceae and Acetobacteraceae, and the order is morphologically, metabolically and ecologically diverse. Most genera in family Rhodospirillaceae grow photoheterotrophically under anoxic conditions in the light and chemotrophically in the dark (Garrity et al., 2005). Members of the family Acetobacteraceae are aerobic acetic acid bacteria that produce acetic acid during their respiration (Sievers \& Swings, 2005a). Detailed comparisons of strain $262-8^{\mathrm{T}}$ with members of these families made it clear that the new strain represented a novel genus in the family Rhodospirillaceae.

White rock was sampled in the Skallen region, Antarctica, and stored at $4{ }^{\circ} \mathrm{C}$ for 6 months. To screen for autotrophic bacteria, rock samples were crushed, added to BG-11 liquid medium (ATCC medium 616) and incubated at $25{ }^{\circ} \mathrm{C}$ in 
the light. The resulting culture was transferred onto BG-11 solid medium. A green filamentous bacterium (strain 262-1), covered with several heterotrophic bacteria, was found by microscopic observation. Multiple attempts to purify single colonies were made but complete removal of the contaminant strains was not achieved. Therefore, an unpurified culture of strain 262-1 was inoculated into $0.10 \times \mathrm{LB}$ agar $\left(\mathrm{l}^{-1}\right.$ tap water: $1.0 \mathrm{~g}$ tryptone, $0.5 \mathrm{~g}$ yeast extract, $5.0 \mathrm{~g} \mathrm{NaCl}, 20 \mathrm{~g}$ agar) and incubated at $25^{\circ} \mathrm{C}$ in the dark. Although strain 262-1 could not grow, several bacterial colonies were formed. The bacterium forming the smallest colony was designated strain $262-8^{\mathrm{T}}$.

The standard medium for cultivation of strain $262-8^{\mathrm{T}}$ was $0.25 \times \mathrm{LB} / \mathrm{MA}$ medium $\left[\mathrm{I}^{-1}\right.$ deionized water: $2.5 \mathrm{~g}$ tryptone, $1.25 \mathrm{~g}$ yeast extract, $6.3 \mathrm{~g}$ Marine Art SF-1 (Tomita Pharmaceutical)]. Strain $262-8^{\mathrm{T}}$ could also grow in $0.25 \times \mathrm{LB} / \mathrm{ASW}$ medium $\left[1^{-1}\right.$ tap water: $2.5 \mathrm{~g}$ tryptone, 1.25 g yeast extract, $5.0 \mathrm{~g} \mathrm{NaCl}, 0.75 \mathrm{~g} \mathrm{MgCl}_{2} .6 \mathrm{H}_{2} \mathrm{O}, 1.5 \mathrm{~g}$ $\mathrm{MgSO}_{4} .7 \mathrm{H}_{2} \mathrm{O}, 0.25 \mathrm{~g}\left(\mathrm{NH}_{4}\right)_{2} \mathrm{SO}_{4}, 0.05 \mathrm{~g} \mathrm{NaHCO}_{3}, 0.075 \mathrm{~g}$ $\mathrm{CaCl}_{2} \cdot 2 \mathrm{H}_{2} \mathrm{O}, 0.125 \mathrm{~g} \mathrm{KCl}, 0.105 \mathrm{~g} \mathrm{KH}_{2} \mathrm{PO}_{4}, 0.0125 \mathrm{~g}$ $\mathrm{NaBr}, 0.005 \mathrm{~g} \mathrm{SrCl}_{2} \cdot 6 \mathrm{H}_{2} \mathrm{O}, 0.025 \mathrm{~g} \mathrm{Fe}\left(\mathrm{NH}_{4}\right)$ citrate] and marine broth 2216 (BD Difco). For solid media, $20 \mathrm{~g}$ agar $1^{-1}$ was added. Strain $262-8^{\mathrm{T}}$ could be stored as a $20 \%$ (v/v) glycerol suspension at $-80{ }^{\circ} \mathrm{C}$ for at least 2 years.

Growth of strain $262-8^{\mathrm{T}}$ at $5-37^{\circ} \mathrm{C}$, at $\mathrm{pH} 4-10$ and with $0-100 \mathrm{~g} \mathrm{NaCl} \mathrm{l}^{-1}$ was determined in $0.25 \times \mathrm{LB}$ medium $\left(1^{-1}\right.$ deionized water: $2.5 \mathrm{~g}$ tryptone, $1.25 \mathrm{~g}$ yeast extract, $5.0 \mathrm{~g} \mathrm{NaCl}$ ). To measure growth rate, the isolate was cultivated in $0.25 \times \mathrm{LB} / \mathrm{MA}$ medium under optimal growth conditions until $\mathrm{OD}_{660}$ reached 0.1 , the preculture was inoculated into the same medium and the increase in $\mathrm{OD}_{660}$ was measured. Catalase and oxidase activity was analysed with standard methods (Smibert \& Krieg, 1994). Hydrogen sulfide production and motility were determined using a modified semi-solid agar medium
[ $\mathrm{l}^{-1}$ deionized water: $0.6 \mathrm{~g}$ peptone, $2.0 \mathrm{~g}$ tryptone, $0.2 \mathrm{~g}$ $\mathrm{Fe}\left(\mathrm{NH}_{4}\right)_{2}\left(\mathrm{SO}_{4}\right)_{2}, 0.2 \mathrm{~g} \mathrm{Na}_{2} \mathrm{~S}_{2} \mathrm{O}_{3}, 5.0 \mathrm{~g} \mathrm{NaCl}, 3.5 \mathrm{~g}$ agar] (Holdeman et al., 1977). To observe spore formation, cells in death phase and after heat treatment were observed by phase-contrast microscopy. Biochemical characteristics were analysed using the API $20 \mathrm{NE}$ and API ZYM systems and sensitivity to antibiotics was examined using the ATB VET system (bioMérieux). Substrate utilization was also studied by comparing growth in a basal medium ( $1.0 \mathrm{~g}$ tryptone, $6.3 \mathrm{~g}$ Marine Art SF-1) with and without a carbon source $(1 \%)$. The organic compounds tested were: sugars (arabinose, fructose, galactose, glucose, lactose, maltose, mannose, raffinose, ribose, sucrose, trehalose and xylose), hydroxyl carbons (erythritol, ethanol, glycerol, mannitol and methanol), organic acids (acetate, adipate, benzoate, butyrate, caproate, caprylate, citrate, fumarate, formate, glycolate, malate, propionate, pyruvate, succinate and valerate) and L-amino acids (alanine, arginine, aspartate, glutamate and glycine). Strain $262-8^{T}$ was cultivated microaerobically using the AnaeroPack MicroAero system (Mitsubishi Gas Chemical) and anaerobically in $0.25 \times \mathrm{LB} / \mathrm{MA}$ medium under light and dark conditions. $\mathrm{CaCO}_{3}$ was used to test acetic acid production (Yamada et al., 2000). Growth of strain $262-8^{\mathrm{T}}$ was also tested on $0.25 \times \mathrm{LB} / \mathrm{ASW}$ medium containing $\left(1^{-1}\right) 5.0 \mathrm{~g} \mathrm{CaCO}_{3}$ and $15.0 \mathrm{~g}$ agar for 3 weeks in aerobic, microaerobic and anaerobic conditions. To determine whether strain $262-8^{\mathrm{T}}$ possessed pigments, the spectra of methanol extracts from cells grown on $0.25 \times \mathrm{LB} / \mathrm{MA}$ agar for 2 weeks were analysed by spectrometry (U-0080D; Hitachi).

Cell size and shape were examined by differential interference microscopy (BX51; Olympus) and cell ultrastructure was observed by scanning electron microscopy (S-4700; Hitachi) and atomic force microscopy (OLS3500; Olympus). For scanning electron microscopy,
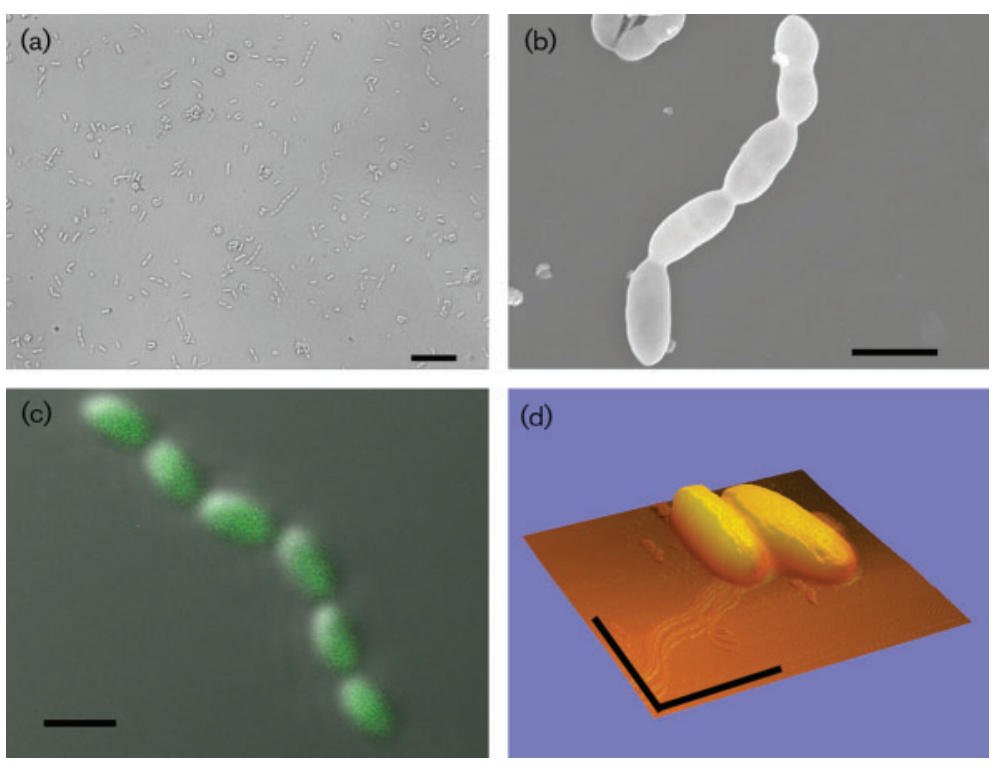

Fig. 1. Micrographs of cells of strain $262-8^{\top}$, using differential interference microscopy (a), scanning electron microscopy (b), confocal laser scanning microscopy and nucleic acid staining with fluorescence reagent (c) and atomic force microscopy (d). Bars, $20 \mu \mathrm{m}$ (a), $2 \mu \mathrm{m}(b-d)$. 
stationary-phase broth was used and the sample was prepared according to the manufacturer's instructions: the sample was freeze-dried with ES-2020 and metallized with a metal evaporator (E-1030). For observation by atomic force microscopy, cells growing in $0.25 \times \mathrm{LB} / \mathrm{MA}$ medium were collected by centrifugation for $5 \mathrm{~min}$, treated with $4 \%$ paraformaldehyde phosphate buffer solution and resuspended. The sample was spread on slides and dried overnight at room temperature. Nucleic acids were visualized by confocal laser scanning microscopy (FV1000;
Olympus) after staining with SYTO 9 dye (Invitrogen), according to the manufacturer's instructions.

To analyse the cellular fatty acid composition, cells of strain $262-8^{\mathrm{T}}$ were cultivated in $0.25 \times \mathrm{LB} / \mathrm{MA}$ medium at $25{ }^{\circ} \mathrm{C}$ until late exponential phase. Cellular fatty acid methyl esters were extracted and purified using a fatty acid methylation kit (Nacalai Tesque). The methyl esters were analysed with a Thermo Scientific GC/MS ITQ900 equipped with a TR-5ms SQC capillary column $(30 \mathrm{~m} \times$

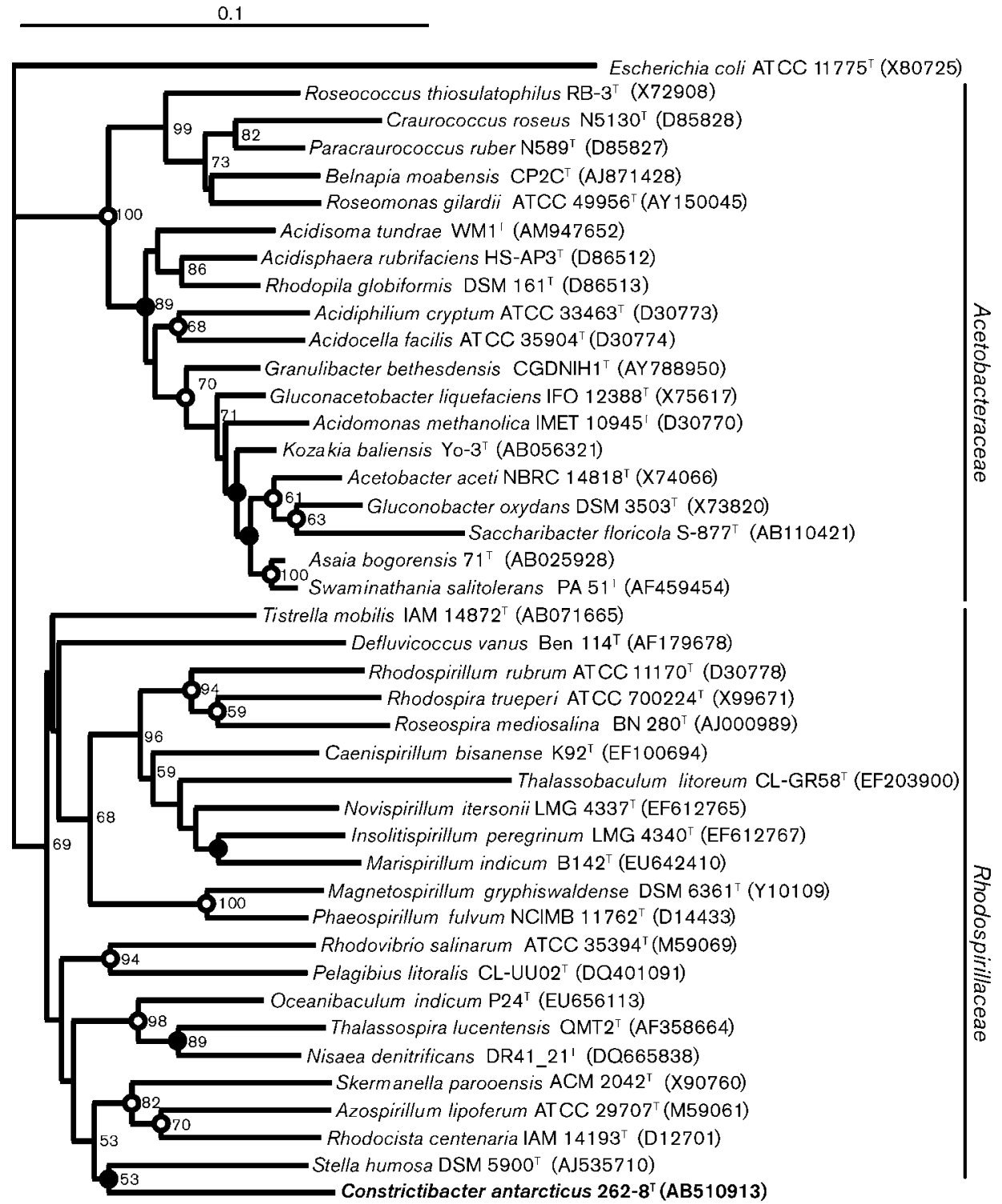

Fig. 2. Neighbour-joining phylogenetic tree of strain $262-8^{\top}$ and members of the order Rhodospirillales based on $16 \mathrm{~S}$ rRNA gene sequences. Bootstrap values $(>50 \%)$ based on 1000 resamplings are shown at branch nodes. Circles indicate that the corresponding nodes were recovered using the maximum-likelihood method (filled circles, $>50 \%$ bootstrap values; open circles, $>70 \%$ bootstrap values). Escherichia coli (ATCC $11775^{\top}$ ) was used as an outgroup. Bar, 10 substitutions per 100 nucleotide positions. 
Table 1. Nucleotides unique to the $16 \mathrm{~S}$ rRNA gene of strain $262-8^{\top}$

Gene sequences listed in Fig. 2 were compared. Positions are according to the Escherichia coli numbering system.

\begin{tabular}{|c|c|c|c|}
\hline $\begin{array}{l}\text { Position } \\
\text { in E. coli }\end{array}$ & $\begin{array}{l}\text { Strain } \\
262-8^{T}\end{array}$ & Rhodospirillaceae & Acetobacteraceae \\
\hline 108 & A & $\mathrm{C}$ or $\mathrm{G}$ & G \\
\hline 262 & G & A & A \\
\hline 630 & $\mathrm{~T}$ & A & G or $A$ \\
\hline 835 & G & $\mathrm{T}$ or $\mathrm{C}$ & $\mathrm{T}$ \\
\hline 852 & $\mathrm{C}$ & G or $A$ & A \\
\hline 1011 & $\mathrm{~T}$ & G or $A$ & A or $\mathrm{G}$ \\
\hline 1214 & A & G & G \\
\hline
\end{tabular}

$0.25 \mathrm{~mm}$; Thermo Fisher Scientific). Quinones were extracted from freeze-dried cells and purified by TLC on Kieselgel 60 F254 plates (Merck) with petroleum ether/ diethyl ether $(85: 15, \mathrm{v} / \mathrm{v})$. The recovered extract of quinones was analysed using a HPTLC RP-18 F254 (Merck) with acetone/acetonitrile $(80: 20, \mathrm{v} / \mathrm{v})$. Q-10 and
Q-8 were used as standards. The $\mathrm{G}+\mathrm{C}$ content was analysed using a GC content of DNA kit (Yamasa Syoyu) and HPLC (LC-10A VP; Shimadzu) equipped with a Cosmosil $5 \mathrm{C}_{18}$ column $(4.6 \times 250 \mathrm{~mm}$; Nacalai Tesque $)$.

The 16S rRNA gene of strain $262-8^{\mathrm{T}}$ was amplified by PCR with KOD-plus DNA polymerase (Toyobo) and two universal primers: $5^{\prime}$-GAGTTTGATCCTGGCTCA-3' and 5'-AAGGAGGTGATCCAGCC-3' (corresponding to positions 9F and 1541R of the Escherichia coli 16S rRNA gene; Brosius et al., 1978). The amplified PCR product was sequenced using an ABI Prism 3100 genetic analyser (Applied Biosystems). To examine the phylogenetic position of strain $262-8^{\mathrm{T}}$, a rooted phylogenetic tree was constructed with $16 \mathrm{~S}$ rRNA gene sequences from bacteria belonging to the order Rhodospirillales using CLUSTAL $\mathrm{W}$ (Thompson et al., 1994).

Strain $262-8^{\mathrm{T}}$ was able to grow in $0.25 \times \mathrm{LB} / \mathrm{MA}, 0.25 \times \mathrm{LB} /$ ASW and marine broth 2216 . The isolate grew at $5-30{ }^{\circ} \mathrm{C}$ (optimum $25{ }^{\circ} \mathrm{C}$ ), but not at $37{ }^{\circ} \mathrm{C}$, at $\mathrm{pH} 6.0-8.0$ (optimum approximately $\mathrm{pH} 7.0$ ) and with $0.10-2.0 \%$ $\mathrm{NaCl}$ (optimum $0.5 \% \mathrm{NaCl}$ ). The maximum $\mathrm{OD}_{660}$ was

Table 2. Characteristics that differentiate strain $262-8^{\top}$ from members of the order Rhodospirillales

Taxa: 1, strain 262-8 ${ }^{\mathrm{T}} ; 2$, Azospirillum (Zhang et al., 2008); 3, Magnetospirillum (Schüler \& Schleifer, 2005; Sizova et al., 2007); 4, Phaeospirillum (Imhoff, 2005c); 5, Rhodocista (Imhoff, 2005d); 6, Rhodospira (Pfennig et al., 1997); 7, Rhodospirillum (Imhoff, 2005a); 8, Rhodovibrio (Imhoff, 2005e); 9, Roseospira (Guyoneaud et al., 2002; Imhoff, 2005b); 10, Skermanella (Sly \& Stackebrandt, 1999; Zhang, et al., 2008; Weon et al., 2007); 11, Stella (Vasilyeva, 2005); 12, Thalassobaculum (Zhang, et al., 2008); 13, Acetobacter (Sievers \& Swings, 2005b); 14, Acidiphilium (Kishimoto et al., 1995); 15, Acidisphaera (Hiraishi et al., 2000); 16, Acidocella (Kishimoto et al., 1995); 17, Acidomonas (Urakami et al., 1989); 18, Asaia (Loganathan \& Nair, 2004; Yamada et al., 2000); 19, Craurococcus (Saitoh et al., 1998); 20, Gluconacetobacter (Sievers \& Swings, 2005d); 21, Gluconobacter (Sievers \& Swings, 2005c); 22, Paracraurococcus (Saitoh et al., 1998); 23, Rhodopila (Madigan \& Imhoff, 2005); 24, Roseococcus (Alarico et al., 2002; Yurkov et al., 1994); 25, Roseomonas (Gallego et al., 2006; Weyant \& Whitney, 2005); 26, Swaminathania (Loganathan \& Nair, 2004). +, Positive; $+/-$, some strains positive; -, negative; NA, not applicable; ND, no data available.

\begin{tabular}{|c|c|c|c|c|c|c|c|c|c|c|c|c|}
\hline \multirow[t]{2}{*}{ Characteristic } & \multirow[b]{2}{*}{1} & \multicolumn{11}{|c|}{ Rhodospirillaceae } \\
\hline & & 2 & 3 & 4 & 5 & 6 & 7 & 8 & 9 & 10 & 11 & 12 \\
\hline Cell morphology* & $\mathrm{O}, \mathrm{R}$ & PV, STR & s & $\mathrm{v}, \mathrm{s}$ & $\mathrm{v}, \mathrm{s}$ & $\mathrm{v}, \mathrm{s}$ & $\mathrm{v}, \mathrm{s}$ & $\mathrm{v}, \mathrm{s}$ & $\mathrm{v}, \mathrm{s}$ & $\mathrm{R}, \mathrm{MC}$ & FSPS & SCSR \\
\hline \multicolumn{13}{|l|}{ Cell characteristics } \\
\hline Width/diameter $(\mu \mathrm{m})$ & $0.8-1$ & $0.6-0.9$ & $0.2-0.7$ & $0.5-1$ & $1-2$ & $1.5-3$ & $0.8-1.5$ & $0.6-0.9$ & $0.6-1$ & $1-1.5$ & $0.7-3$ & $0.3-0.5$ \\
\hline Length $(\mu \mathrm{m})$ & $1.5-2$ & $2-30$ & $1-20$ & $3.5-6$ & 3 & $1.5-3$ & $\mathrm{NA}$ & $1-3.5$ & $1.5-6.5$ & $2-3$ & $\mathrm{NA}$ & $1.3-1.5$ \\
\hline Flagellation & + & + & + & + & + & + & + & + & + & + & - & + \\
\hline \multicolumn{13}{|l|}{$\mathrm{pH}$ for growth } \\
\hline Range & $6-8$ & $5-8.5$ & $\mathrm{ND}$ & $6-8.5$ & $5.7-7$ & $7-7.8$ & $6-8.5$ & $7.5-8$ & $5.3-8.5$ & $4-9$ & Neutral & $7-9$ \\
\hline Optimum & 7 & $5-7.2$ & 7 & 7.3 & 6.8 & $7.3-7.5$ & $6.8-7$ & $\mathrm{ND}$ & $6.7-7$ & $6-7$ & $\mathrm{ND}$ & 8 \\
\hline Major quinone $\dagger$ & Q-10 & Q-10 & Q-10 & $\begin{array}{l}\text { Q-9, } \\
\text { MK-9 }\end{array}$ & Q-9 & $\begin{array}{l}\text { Q-7, } \\
\text { MK-7 }\end{array}$ & $\begin{array}{l}\text { Q-10, } \\
\text { RQ-10 }\end{array}$ & $\begin{array}{l}\text { Q-10, } \\
\text { MK-10 }\end{array}$ & ND & $\begin{array}{r}\text { Q-10, } \\
\text { Q-8 }\end{array}$ & ND & Q-10 \\
\hline Bacteriochlorophyll $a$ & - & - & - & + & + & 一未 & + & + & + & - & $\mathrm{ND}$ & - \\
\hline $\begin{array}{l}\text { Anoxic photosynthethic } \\
\text { growth }\end{array}$ & - & - & - & + & + & + & + & + & + & - & - & $\mathrm{ND}$ \\
\hline DNA G $+\mathrm{C}$ content $(\mathrm{mol} \%)$ & 69.8 & $64-71$ & $63-64$ & $60-66$ & 69.9 & 65.7 & $63-66$ & $65-69$ & $65-68$ & $65-67$ & $69.3-73.5$ & 68.0 \\
\hline Major fatty acids & $\begin{array}{c}\mathrm{C}_{18: 1} \\
\mathrm{C}_{16: 0} \\
\mathrm{C}_{18: 0}\end{array}$ & $\begin{array}{l}\mathrm{C}_{18: 1} \\
\mathrm{C}_{16: 1}\end{array}$ & $\begin{array}{c}\mathrm{C}_{18: 1}, \\
\mathrm{C}_{16: 1} \\
\mathrm{C}_{16: 0}\end{array}$ & $\begin{array}{l}\mathrm{C}_{18: 1} \\
\mathrm{C}_{16: 1}\end{array}$ & $\mathrm{ND}$ & $\begin{array}{r}\mathrm{C}_{18: 1} \\
\mathrm{C}_{16: 0}\end{array}$ & $\begin{array}{l}\mathrm{C}_{18: 1} \\
\mathrm{C}_{16: 1}\end{array}$ & $\begin{array}{l}\mathrm{C}_{18: 1} \\
\mathrm{C}_{18: 0}\end{array}$ & $\mathrm{ND}$ & $\begin{array}{l}\mathrm{C}_{18: 1} \\
\mathrm{C}_{16: 0}\end{array}$ & $\mathrm{ND}$ & $\begin{array}{r}\mathrm{C}_{18: 1}, \\
\mathrm{C}_{17: 0} \\
\mathrm{C}_{16: 0}\end{array}$ \\
\hline
\end{tabular}

${ }^{\star} \mathrm{C}$, coccoid; E, ellipsoid; FSPS, flat, six-pronged stars; MC, multicellular conglomerate; O, ovoid; PCR, plump coccoid rod; PV, plump vibrioid; R, rod; RRE, rod with rounded end; s, spiral; SCSR, slightly curved and straight rods; SPH, spherical; SR, short rod; sTR, straight rod; V, vibrioid.

$\dagger \mathrm{MK}$, menaquinone; $\mathrm{Q}$, ubiquinone; $\mathrm{RQ}$, rhodoquinone.

$\$$ Bacteriochlorophyll $b$ has been detected. 
0.120 , after about $200 \mathrm{~h}$ incubation (doubling time about 36 h; Supplementary Fig. S2). After growth on $0.25 \times \mathrm{LB} /$ MA medium for 2 weeks, colonies were white and circular, with a diameter of $<0.2 \mathrm{~mm}$. Strain $262-8^{\mathrm{T}}$ was able to form colonies microaerobically, but anaerobic growth could not be observed after 2 weeks in either light or dark conditions. Cells were Gram-negative-staining, ovoid to rod-shaped $(0.8-1.0 \times 1.5-2.0 \mu \mathrm{m})$ and often occurred in pairs or chains (Fig. 1a and b). When the location of nucleic acids was observed by confocal laser scanning microscopy, nucleic acids were not observed at the cell constrictions (Fig. 1c). The cytoplasm of each cell was clearly divided, although complete separation of cells was not observed. Motility and flagella could not be observed by scanning electron microscopy (Fig. 1b); however, flagella were observed by atomic force microscopy (Fig. 1d) and motility was observed in semi-solid agar. Strain $262-8^{\mathrm{T}}$ was catalase-positive and oxidase-negative. Production of hydrogen sulfide, acetic acid and spores was not observed. The results of the substrate utilization tests and the API ZYM and ATB VET systems are given in the species description. Although strain $262-8^{\mathrm{T}}$ was resistant to $\beta$-lactam antibiotics, strain $262-8^{\mathrm{T}}$ was sensitive to amoxicillin/clavulanic acid, which suggested that strain $262-8^{\mathrm{T}}$ produced $\beta$-lactamase. Cell growth was not observed for any of the assimilation tests in the API $20 \mathrm{NE}$ system. It seems that the basal medium provided with the kit lacks unknown essential nutrients for the growth of strain $262-8^{\mathrm{T}}$; indeed, complex nutrients such as tryptone or yeast extract are essential. Because no growth was observed in synthetic media, the organic compounds supporting cell growth were determined. Thirteen organic compounds, given in the species description, supported cell growth of strain $262-8^{\mathrm{T}}$.
Comparative analysis of $16 \mathrm{~S}$ rRNA gene sequences indicated that strain $262-8^{\mathrm{T}}$ belonged to the order Rhodospirillales. The most closely related neighbours of strain $262-8^{\mathrm{T}}$ were Stella vacuolata DSM 5901 ${ }^{\mathrm{T}}$ (AJ535711), Stella humosa DSM $5900^{\mathrm{T}}$ and Tistrella mobilis IAM $14872^{\mathrm{T}}$, with which the isolate shared only 90.2, 90.2 and $89.7 \%$ 16S rRNA gene sequence similarity, respectively (Fritz et al., 2004; Shi et al., 2002). The low similarity values suggested that it would be difficult to analyse the phylogenetic position of strain $262-8^{\mathrm{T}}$ by DNA-DNA hybridization. In the neighbour-joining tree (Fig. 2), strain $262-8^{\mathrm{T}}$ was located in the family Rhodospirillaceae and in the same cluster as the genus Stella (Fritz et al., 2004). However, comparison of $16 \mathrm{~S}$ rRNA gene sequences from the families Rhodospirillaceae and Acetobacteraceae revealed that some nucleotides were unique to strain $262-8^{\mathrm{T}}$ : at E. coli positions $108,262,630,835,852$, 1011 and 1214 , only strain $262-8^{\mathrm{T}}$ possessed A, G, T, G, C, T and $\mathrm{A}$, respectively (Table 1 ). Therefore, it was concluded that strain $262-8^{\mathrm{T}}$ belonged to the family Rhodospirillaceae but should be distinguished from the recognized bacteria belonging to the family.

The 16S rRNA gene sequence of strain $262-8^{\mathrm{T}}$ indicated high sequence similarities (99-90\%) with sequences of uncultured bacteria found in environmental samples worldwide (EF157109, EF157242, EU617826, DQ001629, DQ378260, GQ263761, GQ263791, GQ263953 and GQ263966). However, there has been no report of the isolation of these bacteria. In the case of strain $262-8^{\mathrm{T}}$, colonies were very small $(<0.2 \mathrm{~mm})$ and the growth rate was low (doubling time $36 \mathrm{~h}$ ). The isolation of strain $262-8^{\mathrm{T}}$ from the white rock sample was made possible by long-term cultivation and

\begin{tabular}{|c|c|c|c|c|c|c|c|c|c|c|c|c|c|}
\hline \multicolumn{14}{|c|}{ Acetobacteraceae } \\
\hline 13 & 14 & 15 & 16 & 17 & 18 & 19 & 20 & 21 & 22 & 23 & 24 & 25 & 26 \\
\hline$E, R$ & $\mathrm{R}$ & C, SR & $\mathrm{R}$ & RRE & $\mathrm{R}$ & $\mathrm{C}$ & $\mathrm{R}$ & $E, R$ & C & $\mathrm{SPH}, \mathrm{O}$ & $\mathrm{C}$ & PCR & $\mathrm{R}$ \\
\hline $0.6-0.9$ & $0.3-1.2$ & $0.7-0.9$ & $0.5-0.8$ & $0.8-1$ & $0.4-1$ & $0.8-2$ & $0.6-1.2$ & $0.5-1$ & $0.8-1.5$ & $1-2.5$ & $0.9-1.3$ & ND & $0.7-0.9$ \\
\hline $1-4$ & $1-4$ & $0.9-1.6$ & $1-1.8$ & $1.5-3$ & $0.8-2$ & NA & $1-3$ & $2.6-4.2$ & NA & NA & $1.3-1.6$ & ND & $1.9-3.1$ \\
\hline$+1-$ & $+1-$ & - & + & $+1-$ & + & - & $+1-$ & $+1-$ & - & + & + & + & + \\
\hline ND & $2.5-6$ & $3.5-6$ & $3-6$ & $2-5.5$ & ND & ND & ND & ND & ND & $4.2-6.5$ & ND & $5-9$ & ND \\
\hline $4-6$ & ND & $4.5-5$ & ND & $3-5$ & 3 & 7.5 & ND & $5-6$ & $6.6-6.8$ & $4.8-5$ & ND & 7 & ND \\
\hline Q-9 & Q-10 & Q-10 & Q-10 & $\begin{array}{r}\text { Q-10, Q- } \\
9, \text { Q-11 }\end{array}$ & Q-10 & Q-10 & Q-10 & Q-10 & Q-10 & $\begin{array}{l}\text { Q-9/10, } \\
\text { MK-9/10, } \\
\text { RQ-9/10 }\end{array}$ & Q-9 & Q-10 & Q-10 \\
\hline- & + & + & - & - & - & + & - & - & + & + & + & - & ND \\
\hline- & - & - & - & - & - & - & - & - & - & + & - & - & ND \\
\hline $50.5-60.3$ & $63.2-67.5$ & $69.1-69.8$ & $58.7-64.4$ & $63-65$ & $59.3-61.0$ & 70.5 & $54.9-66.4$ & $52-64$ & $70.3-71.0$ & 66.3 & 70.4 & $65-71$ & $57.6-59.9$ \\
\hline $\mathrm{C}_{18: 1}$ & $\mathrm{C}_{18: 1}$ & ND & $\mathrm{C}_{18: 1}$ & $\mathrm{C}_{18: 1}$ & $\begin{array}{c}\mathrm{C}_{18: 1}, \mathrm{C}_{16: 0} \\
\mathrm{C}_{16: 0} 2-\mathrm{OH} \\
\mathrm{C}_{14: 0} 2-\mathrm{OH}\end{array}$ & $\mathrm{C}_{18: 1}$ & $\begin{array}{c}\mathrm{C}_{18: 1} \\
\mathrm{C}_{16: 0}\end{array}$ & $\mathrm{ND}$ & $\mathrm{C}_{18: 1}$ & $\mathrm{C}_{18: 1}$ & $\begin{array}{c}\mathrm{C}_{18: 1}, \mathrm{C}_{18: 1} \\
2-\mathrm{OH}\end{array}$ & $\begin{array}{l}\mathrm{C}_{18: 1}, \mathrm{C}_{18: 1} \\
2-\mathrm{OH}, \mathrm{C}_{15: 0} \\
2-\mathrm{OH} \text { and/or } \\
\mathrm{C}_{16: 1}, \mathrm{C}_{16: 0}\end{array}$ & $\begin{array}{l}\mathrm{C}_{18: 1} \\
\mathrm{C}_{19: 0}\end{array}$ \\
\hline
\end{tabular}


selection of small colonies. These methods will help to isolate novel bacteria from the environment in the future.

Table 2 shows the chemotaxonomic characteristics of strain $262-8^{\mathrm{T}}$ and those of other representatives of genera in the order Rhodospirillales. The major respiratory quinone of strain $262-8^{\mathrm{T}}$ was ubiquinone 10 and the minor quinone was ubiquinone 8 . The cellular fatty acids of strain $262-8^{\mathrm{T}}$ were $\mathrm{C}_{18: 1}(42.7 \%), \mathrm{C}_{16: 0}(32.1 \%), \mathrm{C}_{18: 0}(19.4 \%), \mathrm{C}_{17: 0}$ cyclo $(3.2 \%)$ and $\mathrm{C}_{16: 1}(2.7 \%)$. The $\mathrm{G}+\mathrm{C}$ content of genomic DNA was $69.8 \mathrm{~mol} \%$. These chemotaxonomic characteristics are in agreement with those for other representatives of genera in the order Rhodospirillales (Table 2). However, a few physiological characteristics of strain $262-8^{\mathrm{T}}$ were different from those of the family Rhodospirillaceae. Strain $262-8^{\mathrm{T}}$ could not grow photoheterotrophically under anoxic conditions, contrary to most genera in the family Rhodospirillaceae (Garrity et al., 2005; Vasilyeva, 2005). No spectrum corresponding to the presence of pigments could be observed (data not shown). The result indicated that strain $262-8^{\mathrm{T}}$ contained no bacteriochlorophyll $a$ or other pigments, which agreed with the result that strain $262-8^{\mathrm{T}}$ could not grow photoheterotrophically under anoxic conditions. In addition, strain $262-8^{\mathrm{T}}$ could not grow under acidic conditions and no acid production was observed, as opposed to members of the order Acetobacteraceae (Sievers \& Swings, 2005a).

The order Rhodospirillales of the class Alphaproteobacteria has been divided into two families, Rhodospirillaceae and Acetobacteraceae, by phylogenetic analysis of 16S rRNA gene sequences (Garrity et al., 2005). According to phylogenetic analysis and physiological characteristics, strain $262-8^{\mathrm{T}}$ is a novel bacterium belonging to family Rhodospirillaceae. Therefore, a novel genus and species, Constrictibacter antarcticus gen. nov., sp. nov., is proposed.

\section{Description of Constrictibacter gen. nov.}

Constrictibacter (Cons.tric.ti.bac'ter. L. adj. constrictus compressed, contracted; N.L. masc. n. bacter a rod; N.L. masc. n. Constrictibacter rod with compressed parts).

A member of the class Alphaproteobacteria, order Rhodospirillales, family Rhodospirillaceae. Cells are ovoid to rod-shaped and often occur in pairs or chains. Cells are motile and do not form spores. Grows aerobically or micro-aerobically. The respiratory quinones are Q-10 and Q-8. The major cellular fatty acids are $\mathrm{C}_{18: 1}, \mathrm{C}_{16: 0}$ and $\mathrm{C}_{18: 0}$. The DNA G+C content of the type strain of the type species is $69.8 \mathrm{~mol} \%$.

The type species is Constrictibacter antarcticus.

\section{Description of Constrictibacter antarcticus sp. nov.}

Constrictibacter antarcticus (ant.arc'ti.cus. L. masc. adj. antarcticus pertaining to Antarctica).

Cells are $0.8-1.0 \mu \mathrm{m}$ in diameter and $1.5-2.0 \mu \mathrm{m}$ in length. Colonies are white and circular, $<0.2 \mathrm{~mm}$ in diameter on
$0.25 \times \mathrm{LB} / \mathrm{MA}$ agar. Catalase is produced, but oxidase is not produced. Produces acid phosphatase, alkaline phosphatase, cystine arylamidase, esterase (C4), esterase lipase (C8), $\beta$-glucosidase, leucine arylamidase, lipase (C14), naphtholAS-BI-phosphohydrolase, trypsin and valine arylamidase. Reduces nitrate. Complex nutrients (tryptone or yeast extract) are essential for growth. Grows at $5-30{ }^{\circ} \mathrm{C}$ (optimum $25{ }^{\circ} \mathrm{C}$ ) and $\mathrm{pH}$ 6.0-8.0 (optimum approximately $\mathrm{pH} 7.0$ ). Doubling time is about $36 \mathrm{~h}$ in $0.25 \times \mathrm{LB} /$ MA medium under optimal growth conditions. Ribose, fructose, lactose, sucrose, trehalose, glycerol, glycolate, malate, acetate, succinate, pyruvate, aspartate and glutamate support cell growth. The type strain is resistant to erythromycin, lincomycin, pristinamycin, tylosin, cotrimoxazole, sulfamethizole, nitrofurantoin, fusidic acid, metronidazole, penicillin, amoxicillin, oxacillin, cephalothin, cefoperazone, chloramphenicol and tetracycline, but sensitive to colistin, flumequine, oxolinic acid, enrofloxacin, rifampicin, amoxicillin/clavulanic acid, streptomycin, spectinomycin, kanamycin, gentamicin, apramycin and doxycycline.

The type strain, $262-8^{\mathrm{T}}\left(=\mathrm{JCM} 16422^{\mathrm{T}}=\right.$ ATCC BAA$1906^{\mathrm{T}}$ ), was isolated from a cavity within white rock collected in the Skallen region of Antarctica. The DNA $\mathrm{G}+\mathrm{C}$ content of the type strain is $69.8 \mathrm{~mol} \%$.

\section{Acknowledgements}

The authors would like to express their sincere thanks to all members of the 46th Japanese Antarctic Research Expedition. This study was supported by JSPS KAKENHI (grant number 19205022).

\section{References}

Alarico, S., Rainey, F. A., Empadinhas, N., Schumann, P., Nobre, M. F. \& da Costa, M. S. (2002). Rubritepida flocculans gen. nov., sp. nov., a new slightly thermophilic member of the alpha-1 subclass of the Proteobacteria. Syst Appl Microbiol 25, 198-206.

Bargagli, R. (2005). Antarctica: geomorphology and climate trends. In Antarctic Ecosystems: Environmental Contamination, Climate Change and Human Impact, pp. 1-42. Berlin: Springer-Verlag.

Brosius, J., Palmer, M. L., Kennedy, P. J. \& Noller, H. F. (1978). Complete nucleotide sequence of a $16 \mathrm{~S}$ ribosomal RNA gene from Escherichia coli. Proc Natl Acad Sci U S A 75, 4801-4805.

de la Torre, J. R., Goebel, B. M., Friedmann, E. I. \& Pace, N. R. (2003). Microbial diversity of cryptoendolithic communities from the McMurdo Dry Valleys, Antarctica. Appl Environ Microbiol 69, 3858-3867.

Fritz, I., Strömpl, C. \& Abraham, W. R. (2004). Phylogenetic relationships of the genera Stella, Labrys and Angulomicrobium within the 'Alphaproteobacteria' and description of Angulomicrobium amanitiforme sp. nov. Int J Syst Evol Microbiol 54, 651-657.

Gallego, V., Sánchez-Porro, C., Garcia, M. T. \& Ventosa, A. (2006). Roseomonas aquatica sp. nov., isolated from drinking water. Int J Syst Evol Microbiol 56, 2291-2295.

Garrity, M. G., Bell, J. A. \& Lilburn, T. (2005). Family I, Rhodospirillaceae Pfenning and Trüper 1971, 17 $7^{\mathrm{AL}}$. In Bergey's Manual of Systematic Bacteriology, 2nd edn, vol 2C, pp. 1-40. Edited by D. J. Brenner, N. R. Kreig, J. T. Staley \& G. M. Garrity. New York: Springer. 
Guyoneaud, R., Mouné, S., Eatock, C., Bothorel, V., Hirschler-Réa, A., Willison, J., Duran, R., Liesack, W., Herbert, R. \& other authors (2002). Characterization of three spiral-shaped purple nonsulfur bacteria isolated from coastal lagoon sediments, saline sulfur springs, and microbial mats: emended description of the genus Roseospira and description of Roseospira marina sp. nov., Roseospira navarrensis sp. nov., and Roseospira thiosulfatophila sp. nov. Arch Microbiol 178, 315-324.

Hiraishi, A., Matsuzawa, Y., Kanbe, T. \& Wakao, N. (2000). Acidisphaera rubrifaciens gen. nov., sp. nov., an aerobic bacteriochlorophyll-containing bacterium isolated from acidic environments. Int J Syst Evol Microbiol 50, 1539-1546.

Holdeman, L. V., Cato, E. P. \& Moore, W. E. C. (1977). Anaerobe Laboratory Manual, 4th edn. Blacksburg, VA: Virginia Polytechnic. Institute and State University Anaerobe Laboratory.

Hughes, K. A. \& Lawley, B. (2003). A novel Antarctic microbial endolithic community within gypsum crusts. Environ Microbiol 5, 555-565.

Imhoff, J. F. (2005a). Genus I, Rhodospirillum Molisch 1907, $24^{\mathrm{AL}}$ emend. Imhoff, Petri, and Süling 1998, $796^{\mathrm{VP}}$. In Bergey's Manual of Systematic Bacteriology, 2nd edn, vol 2C, pp. 1-6. Edited by D. J. Brenner, N. R. Kreig, J. T. Staley \& G. M. Garrity. New York: Springer.

Imhoff, J. F. (2005b). Genus IX, Roseospira Imhoff, Petri, and Süling $1998,797^{\mathrm{VP}}$. In Bergey's Manual of Systematic Bacteriology, 2nd edn, vol 2C, pp. 37-38. Edited by D. J. Brenner, N. R. Kreig, J. T. Staley \& G. M. Garrity. New York: Springer.

Imhoff, J. F. (2005c). Genus V, Phaeospirillum Imhoff, Petri, and Süling 1998, $796^{\mathrm{VP}}$. In Bergey's Manual of Systematic Bacteriology, 2nd edn, vol 2C, pp. 32-33. Edited by D. J. Brenner, N. R. Kreig, J. T. Staley \& G. M. Garrity. New York: Springer.

Imhoff, J. F. (2005d). Genus VI, Rhodocista Kawasaki, Hoshino, Kuraishi, and Yamasato 1994b, 182 $\mathrm{VP}$. In Bergey's Manual of Systematic Bacteriology, 2nd edn, vol 2C, pp. 33-35. Edited by D. J. Brenner, N. R. Kreig, J. T. Staley \& G. M. Garrity. New York: Springer.

Imhoff, J. F. (2005e). Genus VIII, Rhodovibrio Imhoff, Petri, and Süling 1998, $797^{\mathrm{VP}}$. In Bergey's Manual of Systematic Bacteriology, 2nd edn, vol 2C, pp. 36-37. Edited by D. J. Brenner, N. R. Kreig, J. T. Staley \& G. M Garrity. New York: Springer.

Karr, E. A., Ng, J. M., Belchik, S. M., Sattley, W. M., Madigan, M. T. \& Achenbach, L. A. (2006). Biodiversity of methanogenic and other archaea in the permanently frozen Lake Fryxell, Antarctica. Appl Environ Microbiol 72, 1663-1666.

Kishimoto, N., Kosako, Y., Wakao, N., Tano, T. \& Hiraishi, A. (1995). Transfer of Acidiphilium facilis and Acidiphilium aminolytica to the genus Acidocella gen. nov., and emendation of the genus Acidiphilium. Syst Appl Microbiol 18, 85-91.

Loganathan, P. \& Nair, S. (2004). Swaminathania salitolerans gen. nov., sp. nov., a salt-tolerant, nitrogen-fixing and phosphatesolubilizing bacterium from wild rice (Porteresia coarctata Tateoka). Int J Syst Evol Microbiol 54, 1185-1190.

Madigan, M. T. \& Imhoff, J. F. (2005). Genus XI, Rhodopila Imhoff, Trüper, and Pfennig 1984, 341 $\mathrm{VP}$. In Bergey's Manual of Systematic Bacteriology, 2nd edn, vol 2C, pp. 83-85. Edited by D. J. Brenner, N. R. Kreig, J. T. Staley \& G. M. Garrity. New York: Springer.

Pfennig, N., Lünsdorf, H., Süling, J. \& Imhoff, J. F. (1997). Rhodospira trueperi gen. nov., spec. nov., a new phototrophic proteobacterium of the alpha group. Arch Microbiol 168, 39-45.

Prisco, G. D. (2007). Lake Vostok and subglacial lakes of Antarctica: do they host life? In Physiology and Biochemistry of Extremophiles, pp. 145-154. Edited by C. Gerday \& N. Glansdorff. New York: American Society for Microbiology.
Priscu, J. C., Fritsen, C. H., Adams, E. E., Giovannoni, S. J., Paerl, H. W., McKay, C. P., Doran, P. T., Gordon, D. A., Lanoil, B. D. \& Pinckney, J. L. (1998). Perennial Antarctic lake ice: an oasis for life in a polar desert. Science 280, 2095-2098.

Saitoh, S., Suzuki, T. \& Nishimura, Y. (1998). Proposal of Craurococcus roseus gen. nov., sp. nov. and Paracraurococcus ruber gen. nov., sp. nov., novel aerobic bacteriochlorophyll a-containing bacteria from soil. Int J Syst Bacteriol 48, 1043-1047.

Schüler, D. \& Schleifer, K. H. (2005). Genus IV, Magnetospirillum Schleifer, Schüler, and Ludwig 1992, $291^{\mathrm{VP}}$. In Bergey's Manual of Systematic Bacteriology, 2nd edn, vol 2C, pp. 28-31. Edited by D. J. Brenner, N. R. Kreig, J. T. Staley \& G. M. Garrity. New York: Springer.

Shi, B. H., Arunpairojana, V., Palakawong, S. \& Yokota, A. (2002). Tistrella mobilis gen nov, sp nov, a novel polyhydroxyalkanoateproducing bacterium belonging to $\alpha$-Proteobacteria. J Gen Appl Microbiol 48, 335-343.

Sievers, M. \& Swings, J. (2005a). Family II, Acetobacteraceae Gillis and De Ley 1980, 23 ${ }^{\mathrm{VP}}$. In Bergey's Manual of Systematic Bacteriology, 2nd edn, vol 2C, pp. 41-96. Edited by D. J. Brenner, N. R. Kreig, J. T. Staley \& G. M. Garrity. New York: Springer.

Sievers, M. \& Swings, J. (2005b). Genus I, Acetobacter Beijerinck $1898,215^{\mathrm{AL}}$. In Bergey's Manual of Systematic Bacteriology, 2nd edn, vol 2C, pp. 51-54. Edited by D. J. Brenner, N. R. Kreig, J. T. Staley \& G. M. Garrity. New York: Springer.

Sievers, M. \& Swings, J. (2005c). Genus IX, Gluconobacter Asai 1935, $689^{\mathrm{AL}}$. In Bergey's Manual of Systematic Bacteriology, 2nd edn, vol 2C, pp. 77-81. Edited by D. J. Brenner, N. R. Kreig, J. T. Staley \& G. M. Garrity. New York: Springer.

Sievers, M. \& Swings, J. (2005d). Genus VIII, Gluconacetobacter Yamada, Hoshino, and Ishikawa 1998b, 32 $\mathrm{VP}$. In Bergey's Manual of Systematic Bacteriology, 2nd edn, vol 2C, pp. 72-73. Edited by D. J. Brenner, N. R. Kreig, J. T. Staley \& G. M. Garrity. New York: Springer.

Sizova, M. V., Panikov, N. S., Spiridonova, E. M., Slobodova, N. V. \& Tourova, T. P. (2007). Novel facultative anaerobic acidotolerant Telmatospirillum siberiense gen. nov. sp. nov. isolated from mesotrophic fen. Syst Appl Microbiol 30, 213-220.

Sly, L. I. \& Stackebrandt, E. (1999). Description of Skermanella parooensis gen. nov., sp. nov. to accommodate Conglomeromonas largomobilis subsp. parooensis following the transfer of Conglomeromonas largomobilis subsp. largomobilis to the genus Azospirillum. Int J Syst Bacteriol 49, 541-544.

Smibert, R. M. \& Krieg, N. R. (1994). Methods for General and Molecular Bacteriology. Washington, DC: American Society for Microbiology.

Thompson, J. D., Higgins, D. G. \& Gibson, T. J. (1994). CLUSTAL W: improving the sensitivity of progressive multiple sequence alignment through sequence weighting, position-specific gap penalties and weight matrix choice. Nucleic Acids Res 22, 4673-4680.

Tindall, B. J. (2004). Prokaryotic diversity in the Antarctic: the tip of the iceberg. Microb Ecol 47, 271-283.

Urakami, T., Tamaoka, J., Suzuki, K. \& Komagata, K. (1989). Acidomonas gen. nov., incorporating Acetobacter methanolicus as Acidomonas methanolica comb. nov. Int J Syst Bacteriol 39, 50-55.

Vasilyeva, L. V. (2005). Genus XIV, Stella Vasilyeva 1985, 520 ${ }^{\mathrm{VP}}$. In Bergey's Manual of Systematic Bacteriology, 2nd edn, vol 2C, pp. 9395. Edited by D. J. Brenner \& N. R. Kreig, J. T. Staley \& G. M. Garrity. New York: Springer.

Weon, H.-Y., Kim, B.-Y., Hong, S.-B., Joa, J.-H., Nam, S.-S., Lee, K. H. \& Kwon, S.-W. (2007). Skermanella aerolata sp. nov., isolated from air, and emended description of the genus Skermanella. Int J Syst Evol Microbiol 57, 1539-1542. 
Weyant, R. S. \& Whitney, A. M. (2005). Genus XIII, Roseomonas Rhis, Brenner, Weaver, Steigerwalt, Hollis, and Yu 1998, 627 VP . In Bergey's Manual of Systematic Bacteriology, 2nd edn, vol 2C, pp. 88-92. Edited by D. J. Brenner, N. R. Kreig, J. T. Staley \& G. M. Garrity. New York: Springer.

Yamada, Y., Katsura, K., Kawasaki, H., Widyastuti, Y., Saono, S., Seki, T., Uchimura, T. \& Komagata, K. (2000). Asaia bogorensis gen. nov., sp. nov., an unusual acetic acid bacterium in the $\alpha$-Proteobacteria. Int J Syst Evol Microbiol 50, 823-829.
Yurkov, V., Stackebrandt, E., Holmes, A., Fuerst, J. A., Hugenholtz, P., Golecki, J., Gad'on, N., Gorlenko, V. M., Kompantseva, E. I. \& Drews, G. (1994). Phylogenetic positions of novel aerobic, bacteriochlorophyll a-containing bacteria and description of Roseococcus thiosulfatophilus gen. nov., sp. nov., Erythromicrobium ramosum gen. nov., sp. nov., and Erythrobacter litoralis sp. nov. Int J Syst Bacteriol 44, 427-434.

Zhang, G. I., Hwang, C. Y. \& Cho, B. C. (2008). Thalassobaculum litoreum gen. nov., sp. nov., a member of the family Rhodospirillaceae isolated from coastal seawater. Int J Syst Evol Microbiol 58, 479-485. 